\title{
Assessment of Fluoride Bioaccumulation Potential in African Catfish (Clarias gariepinus) Reared in Fluoride Rich Water
}

\author{
Jophillene Bejumula ${ }^{1}$ *, Revocatus L Machunda ${ }^{1}$, Liliane J Pasape ${ }^{2}$ and Kelvin M Mtei ${ }^{1}$ \\ ${ }^{l}$ Department of Water and Environmental Science and Engineering (WESE), Nelson Mandela \\ African Institution of Science and Technology (NM-AIST), PO Box 447, Arusha, Tanzania \\ ${ }^{2}$ Department of Business Administration and Management, NM-AIST, PO Box 447, Arusha, \\ Tanzania \\ *Corresponding author: E-mail: jbejumula@gmail.com \\ Co-authors email addresses: revocatus.machunda@nm-aist.ac.tz; liliane.pasape@nm-aist.ac.tz; \\ kelvin.mtei@nm-aist.ac.tz \\ Received 6 Nov 2020, Revised 18 Mar 2021, Accepted 21 Apr 2021, Published May 2021 \\ DOI: https://dx.doi.org/10.4314/tjs.v47i2.6
}

\begin{abstract}
Fluoride bioaccumulation in fish poses a significant impact on their growth, survival and consequently to upper trophic levels. Few studies have reported the impacts of high fluoride concentrations and their accumulation potential to catfish in African settings. A 60-day catfish cultivation was conducted at Ngarenanyuki ward and the Nelson Mandela African Institution of Science and Technology (NM-AIST) in Arusha, Tanzania to determine fluoride bioaccumulation and its impacts to catfish growth and survival. Juvenile catfish were exposed to $36 \mathrm{mg} \mathrm{F}^{-} / \mathrm{L}$ pond water and synthetic water containing fluoride $(\mathrm{NaF})$ concentrations of $5,15,36$ and $45 \mathrm{mg} / \mathrm{L}$ in aquaria set at NM-AIST laboratory. Fluoride concentrations in fish tissues were analysed by ionselective electrode. Fish survival rate was greater than $90 \%$ in $\leq 36 \mathrm{mg} / \mathrm{L}$ fluoride levels compared to $65.8 \%$ in $45 \mathrm{mg} \mathrm{F} / \mathrm{L}$ aquarium. Significant fluoride bioaccumulation was observed in fish bones $(222.00 \mathrm{mg} / \mathrm{kg}$, dry weight), gills $(177.4 \mathrm{mg} / \mathrm{kg})$, skin $(9 \mathrm{mg} / \mathrm{kg})$ and low amount in fillets $(1.467 \mathrm{mg} / \mathrm{kg})$. Fluoride bioaccumulation significantly rose with fluoride levels increase and exposure time $(\mathrm{p}=0.000)$. The study concludes that high fluoride occurrence and its increased exposure time increases fluoride bioaccumulation in African catfish. Therefore, growing catfish in water containing $\geq 45 \mathrm{mg} \mathrm{F}^{-} / \mathrm{L}$ requires defluoridation process.
\end{abstract}

Keywords: African catfish, Aquarium, Fluoride bioaccumulation, Growth performance.

\section{Introduction}

Fluoride toxicity is one of the water quality concerns, and many countries have been declared as endemic for fluoride (Roy and Dass 2013). While most of the water sources are said to have naturally ideal water quality parameters for aquaculture, there are areas with exceptionally high fluoride concentrations. Nevertheless, higher fluoride levels have been reported to pose many health and socioeconomic problems in Tanzania (Mbabaye et al. 2018). Elsewhere in the world, a number of studies have also indicated that fluoride exposure reduces fish growth. Observations by Singh and Tripathi (2015) showed that fluoride concentrations $(10,25$ and $60 \mathrm{mg} / \mathrm{L})$ significantly affected sturgeon fish growth and survival.

Tanzania is one of the top ten countries in the world with high fluoride groundwater concentrations. Others include Australia, China, Ghana, India, Kenya, Sri Lanka, and the 
USA (Jagtap et al. 2012, Kimambo et al. 2019, Rizzu et al. 2020, Addison et al. 2020). Central and northeast regions of Tanzania, especially Singida, Arusha, Shinyanga, Manyara, Mara and Kilimanjaro, are highly affected by higher fluoride levels in water sources (Malago et al. 2017, Thole et al. 2013). Ngarenanyuki ward in Meru District of Arusha region is one of the potential areas for African catfish culture in the North-eastern part of Tanzania, where fluoride levels reach up to $1103.70 \mathrm{mg} / \mathrm{L}$ (Mbabaye et al. 2018). In these areas, ponds for culturing catfish have been increasingly established and filled up with waters from the nearby flowing rivers containing elevated fluoride levels (Mbabaye et al. 2018).

Additionally, most studies conducted in various parts of Africa including Tanzania, have established the baseline information on fluoride occurrences, removal technologies for domestic use, and its impacts to human health (Kut et al. 2016, Demelash et al. 2019,Addison et al. 2020). However, limited information exists on fluoride bioaccumulation, and associated effects on growth and survival of other organisms such as African catfish which are mainly reared in different Tanzania regions. Ghiglieri et al. (2010) reported on some crops grown and irrigated with Ngarenanyuki river water during the dry season in Ngarenanyuki area that accumulated fluoride up to $26 \mathrm{mg} / \mathrm{L}$. Masawe et al. (2019) revealed that maize plants grown in $116.93 \mathrm{mg} \mathrm{F}^{-} / \mathrm{L}$ soil accumulated mean fluoride $\left(\mathrm{mg} \mathrm{F}^{-} / \mathrm{L}\right)$ of $38.560,24.251$, $10.629,7.7756$ and 2.100 in the roots, leaves, stem, grain and cob, respectively. In addition, the bean plants grown in the $129.2 \mathrm{mg} \mathrm{F}^{-} / \mathrm{L}$ soil accumulated mean fluoride in roots, leaves and stem up to $16.27,11.328$ and $8.459 \mathrm{mg} \mathrm{F}^{-} / \mathrm{L}$, respectively. Reported maize and bean grains collected from Ngarenanyuki area contained higher amounts of fluoride than other fluoride endemic areas such as parts of Burundi, India and Ethiopia (Rizzu et al. 2020). Rizzu et al. (2020) revealed on possibilities for the fluoride that accumulated in maize and beans crops to be affiliated with fluoride levels in Ngarenanyuki River and the increasing phosphate fertiliser applications in the farms. Since fluoride is already known to have adverse effects on human health, it is of paramount importance to extend research interests on understanding the growth performance and survival of commercially important fish species farmed in this area, such as African catfish. Based on this ground, the present study was tailored to learn the fluoride bioaccumulation possibilities, growth performance, and survival of the African catfish farmed in fluoride-rich waters in different areas of Tanzania. The findings will contribute to planning for various interventions on addressing the impacts to various aquatic organisms resulting from high levels of fluoride occurrence and exposures and assisting local fish producers to increase their production significantly.

\section{Materials and Methods \\ Study site}

The experiment was carried out for 60 days at Ngarenanyuki ward and the NM-AIST laboratory, located in Arusha, Tanzania (Figure1). A large part of Ngarenanyuki area is dominated by alluvial deposits and volcanic rocks (Ghiglieri et al. 2010). The aquifer in the area and the associated underground rocks are magmatic and metamorphic in nature with high fluoride elements, which affect the high levels of fluoride in most underground and surface waters. Local communities utilise various water sources in the area for numerous domestic and agricultural activities, including fish farming. 
Bejumula et al. - Assessment of fluoride bioaccumulation potential in African catfish ...

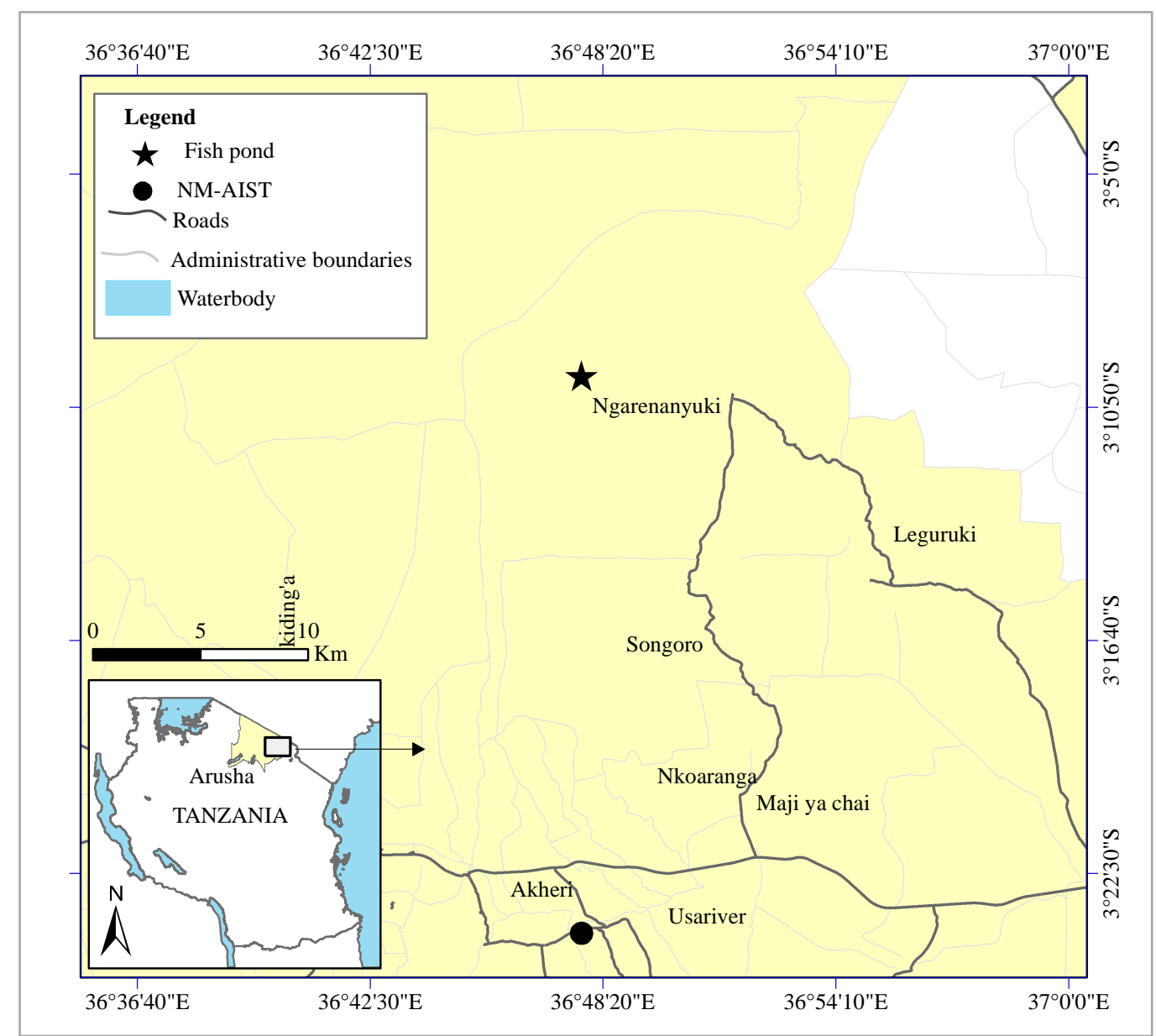

Figure 1: A Map showing Ngarenanyuki ward's location and NM-AIST in Arusha region, Tanzania, where the experiment was conducted. Source: NBS (2019).

\section{Experimental set up}

The first part comprised of four $3.375 \mathrm{~m}^{3}$ aquaria treatments set up at NM-AIST laboratory (Figure 2 (a)) and the second part was made of $36 \mathrm{mg} \mathrm{F}^{-} / \mathrm{L}$ fish pond at Ngarenanyuki secondary school in Ngarenanyuki ward (Figure 2 (b)). To ensure fish sample availability and avoid cannibalism at the end of the experiment, one small compartment of the same volume to aquaria treatments was made using fishnets and inserted in the large fish pond. Out of 4 aquaria treatments, one control aquarium with $36 \mathrm{mg}$ $\mathrm{F} / \mathrm{L}$ of similar fluoride concentrations to the fish pond and other three treatments $(5,15$ and $45 \mathrm{mg} \mathrm{F} / \mathrm{L}$ ) aquaria were set up at NM-AIST laboratory. Bioaccumulation limiting factors namely magnesium $(\mathrm{Mg})$, calcium $(\mathrm{Ca})$ and chloride $\left(\mathrm{Cl}^{-}\right)$were determined from pond waters prior to the experiment to ensure similar fluoride bioaccumulation conditions in the treatments similar to that of the fish pond. The treatment aquaria were filled with multielement standard solutions prepared following the dilution theory (Casellato et al. 2012) and exchanged weekly to control favourable fish growth conditions. These solutions contained the similar concentrations of $\mathrm{Mg}(12.4 \mathrm{mg} / \mathrm{L})$, 
Ca $(13.4 \mathrm{mg} / \mathrm{L})$ and $\mathrm{Cl}^{-}(191.43 \mathrm{mg} / \mathrm{L})$ throughout the treatments as were determined from the fish pond but varied fluoride concentrations in the order of 5, 15, 36 and 45 $\mathrm{mg} / \mathrm{L}$. All treatment aquaria sections were supplied with air using RS Electrical Pump (Model: RS 390) to ensure sufficient dissolved oxygen (DO) levels for fish well-being.

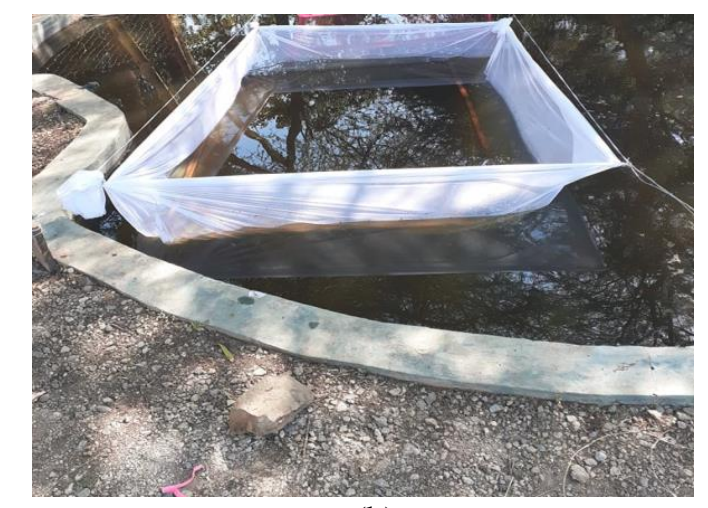

(b)

(b) fishnet compartment in the

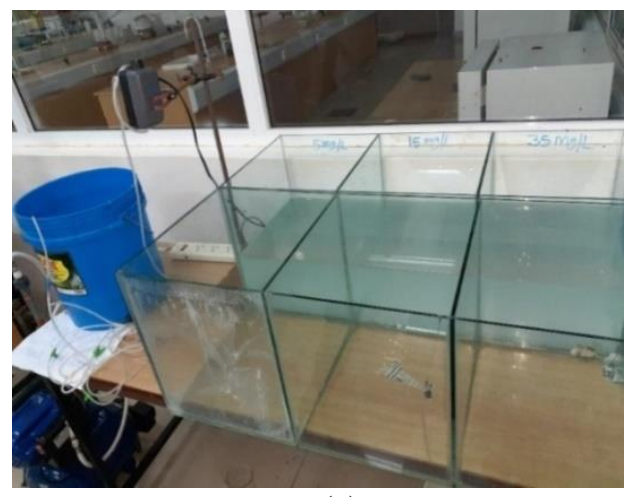

(a)

Figure 2: (a) Aquaria treatments set at
Ngarenanyuki Secondary School fish pond

Best aquaculture practices recommend 10 to 14 days for fish acclimatisation prior stocking (Breves et al. 2011, Abdel-Hay et al. 2020, Olaniyi 2020). Before stocking of catfish fingerlings into the respective aquarium and fish pond compartment, 150 two-month catfish fingerlings reared below $1 \mathrm{mg} / \mathrm{L}$ fluoride water from Moshi Municipality in Kilimanjaro region were acclimatised to experimental conditions for 14 days. The confirmation of the varied fluoride levels was done using a fluoride ionselective electrode method. One hundred and twenty fish fingerlings were stocked in the aquaria treatment each with 30 fingerlings, and the remaining 30 fingerlings out of 150 fingerlings collected were stocked in the fish pond compartment.

\section{Fish feed and feeding schedule}

All fish were fed on industrial synthesised feed pellets procured from TAZAMA Company Limited based in Arusha city, Tanzania throughout the experiment. The feed's nutritional composition was cereals (corn wheat), fish meal, soya bean meal, fish oil, amino acid, calcium phosphate, vitamins and minerals, anti-oxidant and anti-mould.
Generally, the feed contained $40 \%$ of protein and with no fluoride associated ingredients, thus assumed to contribute similar fluoride bioaccumulation trends as all catfish under experiment were fed the same fish feed. During the first month of the experiment, fish juveniles required more protein to boost their growth and thus were fed three times a day at $8.00 \mathrm{am}$, $12.00 \mathrm{pm}$ and $4.00 \mathrm{pm}$ at the rate of $10 \%$ of their body weight, and after that reduced to $5 \%$ of their body weight in the subsequent month (Musiba et al. 2014).

\section{Data collection and analysis Water quality}

Prior to the experimental setup, water samples were collected from Ngarenanyuki fish pond and transported to the NM-AIST Laboratory for determination of fluoride levels and its bioaccumulation limiting factors (hardness and chloride). Fluoride concentrations were determined using fluoride ion-selective electrode method (APHA 2012, Harikumar et al. 2017). Water hardness and chloride were determined by using EDTA titrimetric method and argentometric method, respectively. In each aquarium section, water quality 
Bejumula et al. - Assessment of fluoride bioaccumulation potential in African catfish ...

parameters ( $\mathrm{pH}, \mathrm{DO}$, and temperature) were recorded twice a day; at 09:00 am and 4:00 pm using a $\mathrm{pH}$ meter (HANNA model No. HI 98128) and oxy-guard meter (HANNA model No. HI 98186) (for oxygen and temperature). Water samples were taken from Ngarenanyuki fish pond and aquarium sections weekly, frozen at $\leq-18{ }^{\circ} \mathrm{C}$ in the NM-AIST laboratory where the analyses for ammonia and nitrite concentrations were conducted using phenol method (Parsons et al. 1972).

\section{Growth and survival rate}

Fish weight and length were measured using a weighing balance (OHAUS-Explorer 124, Version 2.01/2.01) and a $30 \mathrm{~cm}$-Fish data ruler, respectively. After every 20 culturing days; at $20^{\text {th }}, 40^{\text {th }}$ and $60^{\text {th }}$ days, three catfish samples were drawn from aquaria treatments and fish pond, temporarily kept in the cooler box and immediately taken to the laboratory for weight and length measurements prior fluoride concentration determination process.

To ensure noticeable changes in growth performances, subsequent weight and length were taken at the beginning of the experiment and after every 20 culturing days ( Lima et al. 2011). Fish mortality was observed daily and dead fish were scooped out of the treatment sections.

To determine fish growth performance and survival rate, fish growth parameters such as weight gain (WG), average daily gain (ADG), specific growth rate (SGR) and survival rate (SR) were calculated by using the formulae as applied in Nawanget al. (2019); $W G=$ Final weight (FW) - Initial weight (IW); $A D G=W G / C$ ulturing days; SGR $=(\ln F W-$ In IW)/Culturing days $\mathrm{x} 100 \% ; S R=$ Fish number at the end of experiment/Fish number at the start of the experiment $\mathrm{x} 100 \%$ ).

\section{Fluoride bioaccumulation}

After every 20 culturing days; at $20^{\text {th }}, 40^{\text {th }}$ and $60^{\text {th }}$ days, three catfish samples from each aquaria treatment and fish compartment in the fish pond were randomly selected and dissected to obtain bones, skin, gills and flesh or fillets tissues for fluoride concentration determination. All sample tissues were stored at $-80{ }^{\circ} \mathrm{C}$ until fluoride analyses were conducted. The samples were then thawed, dried for 6 hours at $105{ }^{\circ} \mathrm{C}$ and ground into powders for fluoride concentration determination (Shi et al. 2009). Fluoride content in various tissues of each fish sample and in respective treatment was determined using fluoride ion-selective electrode method (APHA 2012, Casellato et al. 2012).

\section{Statistical analysis}

Statistical differences in growth performance and fish survival rates were examined using $\mathrm{R}$ software (version 3.6.1) software. The data were presented as mean \pm SE (Standard error of the mean) in tabular and graphical formats. Comparisons in water quality parameters between treatments were tested using Analysis of Variance (ANOVA) and/or Kruskal Wallis, depending on data normality. On the other hand, variations in fluoride content (bioaccumulation) between treatments and between tissues were examined by the $R$ software using Multivariate Analysis of Variance (MANOVA). Results were considered statistically significant at $\mathrm{p}<0.05$.

\section{Results and Discussion Water quality conditions}

In all aquaria treatments and fish pond, water temperatures varied from $17.59{ }^{\circ} \mathrm{C}$ to $27.28{ }^{\circ} \mathrm{C}$. No significant difference in mean temperature was observed between treatments and fish pond $(\mathrm{F}=0.051, \mathrm{p}=0.995)$. $\mathrm{DO}$ varied from $6.89 \mathrm{mg} / \mathrm{L}$ to $7.76 \mathrm{mg} / \mathrm{L}$. No significant difference in DO was observed between aquaria treatments but significantly lower in the fish pond (Kruskal-Wallis $\chi^{2}=$ 36.1, df $=4, \mathrm{p}=0.000)$. Similarly, $\mathrm{pH}$ in aquaria treatments was more or less the same ( $p>0.05$ ) but all being lower compared to that in fish pond water (Kruskal-Wallis $\chi^{2}=15.656$, $\mathrm{df}=4, \mathrm{p}=0.004)$. In the present study, water ammonia and nitrite concentrations were observed to be very low, despite their differences among treatments. In all 
treatments, nitrite and ammonia varied from $0.1756 \mathrm{mg} / \mathrm{L}$ to $0.3928 \mathrm{mg} / \mathrm{L}$ and $0.0008 \mathrm{mg} / \mathrm{L}$ to $0.0056 \mathrm{mg} / \mathrm{L}$, respectively, even though their values were relatively higher in ponds compared to that in experimental aquaria $(\mathrm{p}>$ 0.05). This might have been caused by increased accumulation of fish feed, and debris resulted from less water exchange frequency in the fish pond. Fluoride concentration in the Ngarenanyuki River was reported to range between 26 and $30 \mathrm{mg} / \mathrm{L}$ (Malago et al. 2017, Mbabaye et al. 2018). However, water from the fish pond that was analysed during this study was found to contain $36 \mathrm{mg} \mathrm{F}^{-} / \mathrm{L}$. The water quality parameters recorded during the experiment were found to be within the range recommended for the Clarias gariepinus rearing (Schram et al. 2010, Roques et al. 2015).

A similar observation to the recorded water temperature, $\mathrm{pH}$ and $\mathrm{DO}$ during this study was reported by Umaru et al. (2016) that recorded water temperatures of $20.0{ }^{\circ} \mathrm{C}$ to $33.7{ }^{\circ} \mathrm{C}$, pH of 6.88 to 8.51 and the DO of $4.2 \mathrm{mg} / \mathrm{L}$ to 7.76 $\mathrm{mg} / \mathrm{L}$ while rearing African catfish (Clarias gariepinus) to observe their growth performances. Previous researchers opined that to prevent the risk of reduced growth and feed intake in African catfish culture, water ammonia should not exceed $0.34 \mathrm{mg} / \mathrm{L}$ (Schram et al. 2010), while that of nitrite should be less than $0.6 \mathrm{mg} / \mathrm{L}$ (Roques et al. 2015).

Effects of high fluoride levels on African catfish growth

At the beginning of 60 culturing days of the experiment, catfish weight and length were not significantly different from each other in all treatments $(p>0.05)$, albeit a significant difference was observed among treatments at the end of the experiment $(p<0.05)$ (Table 1).

Pairwise comparisons using Wilcoxon rank-sum test indicated the highest ADG for catfish reared at fluoride level of $5 \mathrm{mg} / \mathrm{L}$, compared to those raised at higher fluoride levels aquaria and fish pond $(p \geq 0.001)$. In Figure 3 (b) while the $36 \mathrm{mg} \mathrm{F}^{-} / \mathrm{L}$ fish pond and $36 \mathrm{mg} \mathrm{F} / \mathrm{L}$ experimental aquarium showed no significant difference in ADG, lower ADG values were recorded in catfish reared at $45 \mathrm{mg}$ $\mathrm{F} / \mathrm{L}$ aquarium. Specific growth rate (SGR) determined was found to be highest in catfish raised in $5 \mathrm{mg} \mathrm{F}^{-} / \mathrm{L}$ and $15 \mathrm{mg} \mathrm{F}^{-} / \mathrm{L}$ aquaria compared to those reared at $36 \mathrm{mg} \mathrm{F}^{-} / \mathrm{L}$ and 45 $\mathrm{mg} \mathrm{F}^{-} / \mathrm{L}$ waters as depicted in Figure 3 (c). However, SGR was lowest in catfish grown at $45 \mathrm{mg} \mathrm{F}^{-} / \mathrm{L}$ aquarium than $36 \mathrm{mg} \mathrm{F}^{-} / \mathrm{L}$ aquarium and fish pond. These findings align with those reported by Shi et al. (2009) on Siberian sturgeon (Acipenser baerii), which showed better fish SGR at lower fluoride concentrations, such as $3.1 \mathrm{mg} / \mathrm{L}$ and 0.26 $\mathrm{mg} / \mathrm{L}$, than those in higher fluoride levels such as 7.8, 18.7, and $51.8 \mathrm{mg} / \mathrm{L}$. Also, Chen et al. (2013) observed that weight gain and specific growth rate decreased significantly as a function of both fluoride concentration and exposure time in freshwater common carp (Cyprinus carpio).

The findings in the present study indicate decreasing WG, ADG and SGR with increasing fluoride media concentrations and fluoride bioaccumulation in catfish reared in both aquaria and ponds. These findings are supported by Kaur et al. (2017) and Nawang et al. (2019) who also reported on the loss of body weight in the freshwater catfish Heteropneustes fossilis with increasing fluoride concentrations. 
Bejumula et al. - Assessment of fluoride bioaccumulation potential in African catfish ...

Table 1: The growth performance of catfish at different fluoride levels (Data source: Recorded data from study experiment, $\mathrm{N}=45$ )

\begin{tabular}{|c|c|c|c|c|c|c|}
\hline \multicolumn{7}{|c|}{ Treatments } \\
\hline $\begin{array}{l}\text { Growth } \\
\text { parameters }\end{array}$ & $\mathrm{n}$ & $\begin{array}{l}5 \mathrm{mg} \mathrm{F} / \mathrm{L} \\
\text { aquaria }\end{array}$ & $\begin{array}{l}15 \mathrm{mg} \mathrm{F} / \mathrm{L} \\
\text { aquaria }\end{array}$ & $\begin{array}{l}36 \mathrm{mg} \mathrm{F} / \mathrm{L} \\
\text { aquaria }\end{array}$ & $\begin{array}{l}36 \mathrm{mg} \mathrm{F} / \mathrm{L} \\
\text { fish pond }\end{array}$ & $\begin{array}{l}45 \mathrm{mg} \mathrm{F} / \mathrm{L} \\
\text { aquaria }\end{array}$ \\
\hline $\begin{array}{l}\text { Initial mean body } \\
\text { weight }(\mathrm{g})\end{array}$ & & $19.92 \pm 1.03$ & $19.89 \pm 1.11$ & $19.88 \pm 1.49$ & $19.87 \pm 0.68$ & $19.9 \pm 0.88$ \\
\hline $\begin{array}{l}\text { Final mean body } \\
\text { weight @ } 20 \text { days } \\
\text { (g) }\end{array}$ & 15 & $53.98 \pm 0.96$ & $44.06 \pm 0.67$ & $43.59 \pm 1.51$ & $43.52 \pm 0.98$ & $38.06 \pm 1.35$ \\
\hline $\begin{array}{l}\text { Final mean body } \\
\text { weight @ } 40 \\
\text { days }(g)\end{array}$ & 15 & $79.99 \pm 1.09$ & $64.03 \pm 0.78$ & $59.05 \pm 1.33$ & $59.00 \pm 1.09$ & $50.77 \pm 1.04$ \\
\hline $\begin{array}{l}\text { Final mean body } \\
\text { weight @ } 60 \\
\text { days }(g)\end{array}$ & 15 & $93.6 \pm 1.11$ & $76.80 \pm 1.00$ & $69.89 \pm 1.29$ & $70.00 \pm 1.14$ & $57.23 \pm 1.68$ \\
\hline $\begin{array}{l}\text { WG @ } 20 \text { days } \\
\text { (g) }\end{array}$ & & $34.06 \pm 0.37$ & $24.17 \pm 0.33$ & $23.71 \pm 0.40$ & $23.65 \pm 0.35$ & $18.16 \pm 0.31$ \\
\hline $\begin{array}{l}\text { WG @ } 40 \text { days } \\
\text { (g) }\end{array}$ & & $26.01 \pm 0.69$ & $19.97 \pm 0.57$ & $15.46 \pm 0.55$ & $15.48 \pm 0.69$ & $12.71 \pm 0.48$ \\
\hline $\begin{array}{l}\text { WG @ } 60 \text { days } \\
\text { (g) }\end{array}$ & & $13.61 \pm 1.07$ & $12.77 \pm 1.41$ & $10.84 \pm 1.63$ & $11.00 \pm 1.02$ & $6.46 \pm 1.59$ \\
\hline $\begin{array}{l}\text { ADG @ } 20 \text { days } \\
\text { (g) }\end{array}$ & & $1.7030 \pm 0.02$ & $1.2085 \pm 0.03$ & $1.1855 \pm 0.04$ & $1.1825 \pm 0.01$ & $0.9080 \pm 0.01$ \\
\hline $\begin{array}{l}\text { ADG @ } 40 \text { days } \\
\text { (g) }\end{array}$ & & $1.3005 \pm 0.03$ & $0.9985 \pm 0.04$ & $0.7730 \pm 0.04$ & $0.7740 \pm 0.06$ & $0.6355 \pm 0.03$ \\
\hline $\begin{array}{l}\text { ADG @ } 60 \text { days } \\
\text { (g) }\end{array}$ & & $0.6805 \pm 0.09$ & $0.6385 \pm 0.08$ & $0.5420 \pm 0.09$ & $0.5500 \pm 0.10$ & $0.3230 \pm 0.07$ \\
\hline SGR @ 20 days & & $0.0498 \pm 0.00$ & $0.0398 \pm 0.00$ & $0.0393 \pm 0.00$ & $0.0392 \pm 0.00$ & $0.0324 \pm 0.00$ \\
\hline (\%/day) & & 0 & 0 & 0 & 1 & 0 \\
\hline SGR @ 40 days & & $0.0197 \pm 0.00$ & $0.0187 \pm 0.00$ & $0.0152 \pm 0.00$ & $0.0152 \pm 0.00$ & $0.0144 \pm 0.00$ \\
\hline SGR@60 days & & $0.0079 \pm 0.00$ & $0.0091 \pm 0.00$ & $0.0084 \pm 0.00$ & $0.0085 \pm 0.00$ & $0.0060 \pm 0.00$ \\
\hline (\%/day) & & 1 & 0 & 6 & 3 & 4 \\
\hline $\begin{array}{l}\text { Mean initial } \\
\text { length }(\mathrm{cm})\end{array}$ & & $16.05 \pm 1.07$ & $16.06 \pm 1.04$ & $16.05 \pm 1.04$ & $16.05 \pm 1.06$ & $16.05 \pm 1.03$ \\
\hline $\begin{array}{l}\text { Mean final } \\
\text { length/fish }(\mathrm{cm})\end{array}$ & & $34.06 \pm 0.06$ & $36.04 \pm 0.06$ & $37.03 \pm 4.05$ & $37.03 \pm 7.03$ & $40.05 \pm 10.02$ \\
\hline Length gain $(\mathrm{cm})$ & & $18.01 \pm 1.65$ & $19.98 \pm 1.48$ & $20.98 \pm 1.57$ & $20.98 \pm 1.61$ & $24 \pm 1.63$ \\
\hline Mean SR (\%) & & 97.78 & 96.26 & 91.21 & 93.61 & 65.79 \\
\hline
\end{tabular}

Note; WG: Weight gain, ADG: Average daily weight gain, SGR: Specific growth rate, SR: Survival rate, $n$ : Number of fish samples measured for determining changes in fish length and weight, $N$ : Total number of fish samples measured for recording and computing growth performance and survival rate parameters. 
(a)

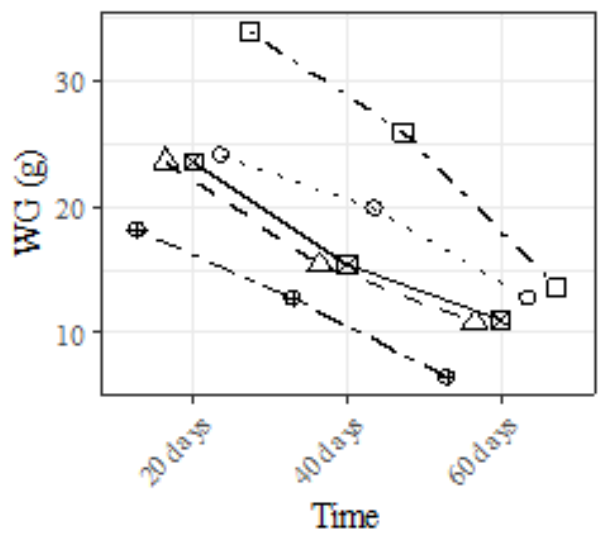

(c)

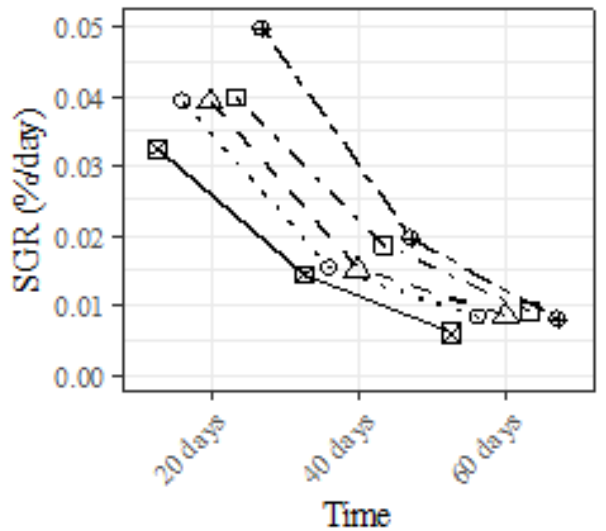

Treatment $\cdot \square$ F5EX $\cdot \Theta \cdot$ F15EX (b)

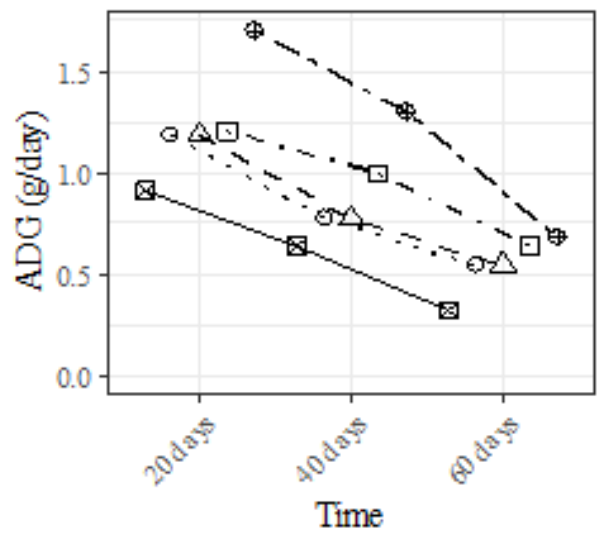

(d)

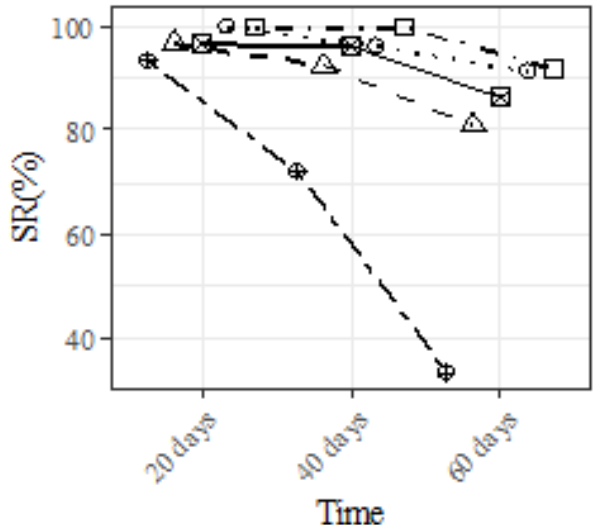

F36EX F36POND F45EX

Figure 3: Growth performance of catfishes reared at different fluoride concentrations.

Note: Treatments abbreviated F5EX, F15EX, F36EX, F45EX, F36POND stand for 5, 15,36, $45 \mathrm{mg}$ $F / L$ aquarium and $36 \mathrm{mg} F / L$ fish pond respectively, whereas WG: Weight gain, ADG: Average daily weight gain, SGR: Specific growth rate, SR: Survival rate.

African catfish survival rates reared in fluoride-rich water levels

At the end of 60 culturing days experiment, treatments with $5 \mathrm{mg} \mathrm{F}^{-} / \mathrm{L}$ and $15 \mathrm{mg} \mathrm{F}^{-} / \mathrm{L}$ were found to have a highest mean survival rates of $97.8 \%$ and $96.3 \%$, respectively and slightly dropped to $91.2 \%$ and $93.6 \%$ in the 36 $\mathrm{mg} \mathrm{F} / \mathrm{L}$ aquarium treatment and fish pond, respectively (Figure 3 (d)). The results indicated a fall in fish mean survival rate
$(65.8 \%)$ in the $45 \mathrm{mg} \mathrm{F}^{-} / \mathrm{L}$ treatment. The average mean survival rate was $97.3 \%$ in the early 20 culturing days, fell to $91.4 \%$ and $76.7 \%$ at the end of $40^{\text {th }}$ and $60^{\text {th }}$ culturing days, respectively. Since the environmental and dietary conditions were adequate throughout the experiment, the reduced fish mean survival rate might have been caused by increased fluoride bioaccumulation trends as reflected in Figure 4 (a) and (b). Additionally, 53\% of fish 
Bejumula et al. - Assessment of fluoride bioaccumulation potential in African catfish ...

mortalities that occurred during the last 20 culturing days of the experiment were recorded in the $45 \mathrm{mg} \mathrm{F}^{-} / \mathrm{L}$ aquarium followed by $36 \mathrm{mg}$ $\mathrm{F} / \mathrm{L}$ aquarium $(19.4 \%), 36 \mathrm{mg} \mathrm{F}^{-} / \mathrm{L}$ fish pond (13.8\%), $15 \mathrm{mg} \mathrm{F}^{-} / \mathrm{L}(8.3 \%)$ and lowest at $5 \mathrm{mg}$ $\mathrm{F} / \mathrm{L}(5.5 \%)$ aquarium as seen in Figure $3(\mathrm{~d})$, and these fish mortalities might have been contributed by a significant increase of bioaccumulation trends with an increase of exposure time.

\section{Fluoride bioaccumulation in different tissues} A two-way MANOVA test indicated significant differences in fluoride tissue concentrations between treatments and exposure time (Table 2 and 3). The highest bioaccumulation levels were found during the last 20 culturing days (between $40^{\text {th }}$ to $60^{\text {th }}$ culturing days) of the experiment in catfish reared at $45 \mathrm{mg} \mathrm{F}^{-} / \mathrm{L}$. There was a great fluoride bioaccumulation tendency in fish bones followed by gills, skin and very rare in the fish flesh and that bioaccumulation significantly increased at $40^{\text {th }}$ culturing day to $60^{\text {th }}$ culturing day due to increasing exposure time (Figure 4(a)). Generally, the level of fluoride bioaccumulation to both catfish reared in aquaria treatments, and fish ponds in different tissues increased with increase in fluoride media concentration and exposure time (Figure 4(a) and (b)). A Tukey multiple comparison of means indicated that the fish reared in the pond with $36 \mathrm{mg} \mathrm{F}^{-} / \mathrm{L}$ had significant higher fluoride bioaccumulation in all tissues compared to experimental aquaria in $5 \mathrm{mg} \mathrm{F}^{-} / \mathrm{L}, 15 \mathrm{mg} \mathrm{F}^{-} / \mathrm{L}$ and $36 \mathrm{mg} \mathrm{F}^{-} / \mathrm{L}$, except for $45 \mathrm{mg} \mathrm{F}^{-} / \mathrm{L}$ aquarium $(\mathrm{p}=0.000)$.

Table 2: Three-way ANOVA test for statistical differences in fluoride bioaccumulation levels among tissues of the catfish

\begin{tabular}{|c|c|c|c|c|c|c|c|}
\hline Predictor & $\begin{array}{l}\text { Sum of } \\
\text { Squares }\end{array}$ & $d f$ & $\begin{array}{c}\text { Mean } \\
\text { Square }\end{array}$ & $F$ & $p$ & partial $\eta^{2}$ & $\begin{array}{c}\text { partial } \eta^{2} \\
90 \% \text { CI } \\
{[\mathrm{LL}, \mathrm{UL}]}\end{array}$ \\
\hline Time & 83986.54 & 1 & 83986.54 & 39.24 & 0.000 & 0.66 & \\
\hline Treatment & 71499.86 & 4 & 17874.97 & 8.35 & 0.000 & 0.63 & {$[0.28,0.71]$} \\
\hline Tissues & 530007.19 & 3 & 176669.06 & 82.54 & 0.000 & 0.93 & {$[0.84,0.94]$} \\
\hline $\begin{array}{l}\text { Time } \quad x \\
\text { Treatment }\end{array}$ & 30251.50 & 4 & 7562.88 & 3.53 & 0.025 & 0.41 & {$[0.04,0.53]$} \\
\hline $\begin{array}{l}\text { Time } \quad x \\
\text { Tissues }\end{array}$ & 59686.70 & 3 & 19895.57 & 9.30 & 0.000 & 0.58 & {$[0.25,0.68]$} \\
\hline $\begin{array}{l}\text { Treatment } \\
\mathrm{x} \text { Tissues }\end{array}$ & 55949.24 & 12 & 4662.44 & 2.18 & 0.060 & 0.57 & {$[0.00,0.54]$} \\
\hline Time $\quad \mathrm{x}$ & & & & & & & \\
\hline $\begin{array}{l}\text { Treatment } \\
\mathrm{x} \text { Tissues }\end{array}$ & 20691.84 & 12 & 1724.32 & 0.81 & 0.642 & 0.33 & {$[0.00,0.24]$} \\
\hline Error & 42807.04 & 20 & 2140.35 & & & & \\
\hline
\end{tabular}


Table 3: Mean concentration ( $\mathrm{mg} \mathrm{F}^{-} / \mathrm{kg}$ dry weight, in Clarias gariepinus exposed to waterborne fluoride for 60 culturing days. (Data source: Recorded data from study experiment) $(\mathrm{N}=60)$

\begin{tabular}{llll}
\hline Tissues & Treatments & Mean values $(\mathrm{mg} \mathrm{F} / \mathrm{kg})$ & $\mathrm{n}$ \\
\hline Bone & $5 \mathrm{mg} \mathrm{F} / \mathrm{L}$ aquaria & $119.09 \pm 0.55$ & 3 \\
& $15 \mathrm{mg} \mathrm{F} / \mathrm{L}$ aquaria & $156.46 \pm 61.52$ & 3 \\
& $36 \mathrm{mg} \mathrm{F} / \mathrm{L}$ aquaria & $233.38 \pm 155.48$ & 3 \\
& $36 \mathrm{mg} \mathrm{F} / \mathrm{L}$ fish pond & $234.01 \pm 155.76$ & 3 \\
& $45 \mathrm{mg} \mathrm{F} / \mathrm{L}$ aquaria & $368.40 \pm 130.26$ & 3 \\
\hline Fillets & $5 \mathrm{mg} \mathrm{F} / \mathrm{L}$ aquaria & $0.28 \pm 0.06$ & 3 \\
& $15 \mathrm{mg} \mathrm{F} / \mathrm{L}$ aquaria & $0.41 \pm 0.03$ & 3 \\
& $36 \mathrm{mg} \mathrm{F} / \mathrm{L}$ aquaria & $1.64 \pm 1.35$ & 3 \\
& $36 \mathrm{mg} \mathrm{F} / \mathrm{L}$ fish pond & $2.14 \pm 1.49$ & 3 \\
& $45 \mathrm{mg} \mathrm{F} / \mathrm{L}$ aquaria & $2.86 \pm 2.05$ & 3 \\
\hline Gills & $5 \mathrm{mg} \mathrm{F} / \mathrm{L}$ aquaria & $112.03 \pm 0.04$ & 3 \\
& $15 \mathrm{mg} \mathrm{F} / \mathrm{L}$ aquaria & $114.66 \pm 0.66$ & 3 \\
& $36 \mathrm{mg} \mathrm{F} / \mathrm{L}$ aquaria & $206.66 \pm 124.31$ & 3 \\
\hline Skin & $36 \mathrm{mg} \mathrm{F} / \mathrm{L}$ fish pond & $207.51 \pm 124.99$ & 3 \\
& $45 \mathrm{mg} \mathrm{F} / \mathrm{L}$ aquaria & $244.82 \pm 135.32$ & 3 \\
& $5 \mathrm{mg} \mathrm{F} / \mathrm{L}$ aquaria & $7.95 \pm 0.36$ & 3 \\
& $15 \mathrm{mg} \mathrm{F} / \mathrm{L}$ aquaria & $9.62 \pm 0.96$ & 3 \\
\hline
\end{tabular}

Note: The abbreviations, $n$ stands for number of fish samples tested for fluoride bioaccumulation into their tissue for every observation in each aquarium and fish pond, whereby $N=$ total number of fish samples tested for fluoride bioaccumulation into their tissues.

While studying the bioaccumulation of fluoride in 4 tilapia fishes (Tilapia nilotica, $T$. zilii, T. leucost and Micropterus salmoides) from lakes of the Great Rift Valley in Kenya (Gikunju et al. 1992) found high fluoride concentrations ranging from 117 to $211 \mathrm{mg} \mathrm{F}^{-}$ $/ \mathrm{kg}$ and from 1.3 to $3 \mathrm{mg} \mathrm{F^{- }} / \mathrm{kg}$ in the fish bones and fillets, respectively. Shi et al. (2009) found a maximum fluoride concentration of $3204.4 \mathrm{mg} \mathrm{kg}^{-1}$ in bones, $1401.2 \mathrm{mg} \mathrm{kg}^{-1}$ in cartilage, $100.1 \mathrm{mg} \mathrm{kg}^{-1}$ in skin and $5.2 \mathrm{mg} \mathrm{kg}^{-}$ 1 in muscles of the Siberian sturgeon (Acipenser baerii). Also, El-Said et al. (2015) reported high fluoride contents in bones but less in flesh tissues of the Egyptian Tilapia nilotica. El-Said et al. (2015) findings also support the present study's results suggesting fluoride bioaccumulation resulted from the aquatic medium.

It will be important to ensure well-known water fluoride levels by fish growers in the area to ensure high fish production reared from elevated fluoride levels that can affect fish growth and survival rates. Studies with extended cultivation periods with more observations need to be conducted to explore other fluoride bioaccumulation possibilities, and associated impacts on African catfish reared in the fluoride-rich waters. 
Bejumula et al. - Assessment of fluoride bioaccumulation potential in African catfish ...

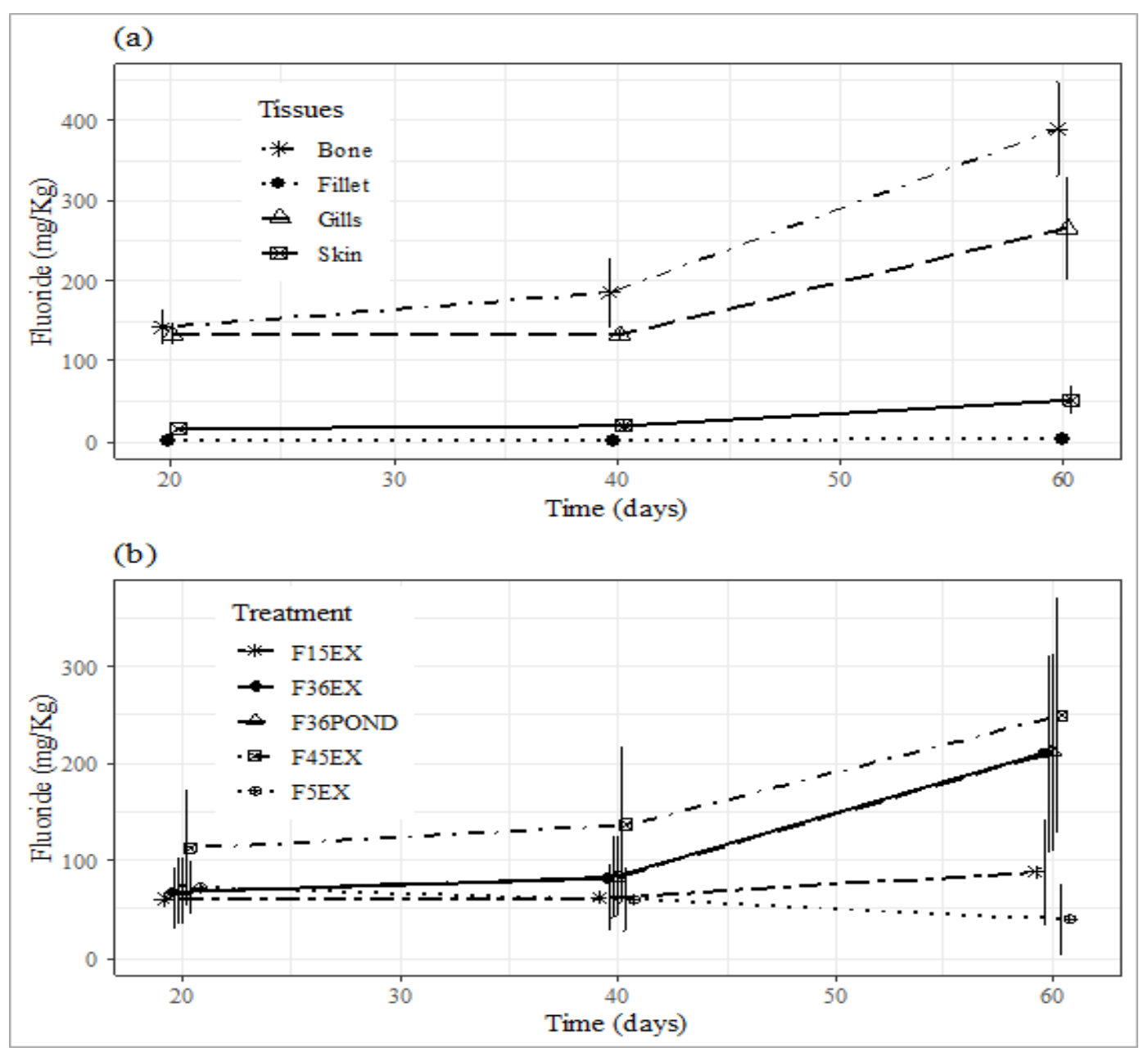

Figure 4: Fluoride bioaccumulation in catfish tissues during the culturing period.

Note: The abbreviations "F5EX", "F15EX", "F36EX", and "F45EX", respectively represent aquaria with $5 \mathrm{mg} F / L, 15 \mathrm{mg} F / L, 36 \mathrm{mg} F / L$ and $45 \mathrm{mg} F / L$, while "F36POND" represents 36 $m g F / L$ in fish pond.

\section{Conclusion}

The study found significant amounts of fluoride bioaccumulated in catfish reared in fluoride-rich waters. The fluoride bioaccumulation trends increased with water media fluoride concentrations and exposure time. Significant differences in mean fluoride bioaccumulation were revealed in Clarias gariepinus tissues, the bones being the portions of the fish with elevated amounts of fluoride concentrations. High fluoride bioaccumulation trends occurred at the last 20 culturing days as compared to first 20 culturing days of the experiment. The results revealed that catfish growth and survival rates reared in $5 \mathrm{mg} \mathrm{F} / \mathrm{L}$ up to $36 \mathrm{mg} \mathrm{F} / \mathrm{L}$ waters were not highly affected compared to catfish grown above 45 $\mathrm{mg} \mathrm{F} / \mathrm{L}$ aquarium treatment waters. Based on the present study's findings, it was concluded that the occurrence of high levels of fluoride waters in Ngarenanyuki area could accelerate increasing fluoride bioaccumulation in African 
catfish and contribute to the reduced growth and survival rate of catfish reared in the area. The current study was conducted for only two months due to time and budgetary constraints. This short-time experimentation may have affected revealing realities on the fluoride bioaccumulation trends and levels in catfish. It is therefore recommended that future studies should extend the observation period for more refined findings.

\section{Acknowledgements}

The authors are grateful to the African Centre of Excellence (ACE II) Program for funding the study and, therefore, stretching thankful note to the Nelson Mandela African Institution of Science and Technology for a cordially collaboration in managing the funds to the end of the study. Additionally, we truly honour the cooperation shown by the Ngarenanyuki Secondary School and Ngurdoto Defluoridation Research Station administration for their readiness and assistance during this study.

\section{References}

Abdel-Hay AHM, Emam W, Omar AA, Eltras WF and Mohamed RA 2020 The effects of rearing water depths and feed types on the growth performance of African catfish (Clarias gariepinus). Aquacult. Res. 51(2): 616-622.

Addison MJ, Rivett MO, Robinson H, Fraser A, Miller AM, Phiri P, Mleta Pand Kalin RM 2020 Fluoride occurrence in the lower East African rift system, southern Malawi. Sci. Total Environ. 712: 136260.

APHA/AWWA/WEF 2012 Standard methods for the examination of water and wastewater. $56^{\text {th }}$ ed, Am. J. Public Health and the Nations Health, Washington DC

Breves JP, Seale AP, Helms RE, Tipsmark CK, Hirano T and Grau EG 2011 Dynamic gene expression of GH/PRL-family hormone receptors in gill and kidney during freshwater-acclimation of Mozambique tilapia. Comp. Biochem. Physiol., Part A: Mol. Integr. Physiol. 158(2): 194-200.
Casellato S, Masiero L and Ballarin L 2012 Toxicity of fluoride to the freshwater mollusc Dreissena polymorpha: effects on survival, histology, and antioxidant enzyme activity. Fluoride 45: 35-46.

Chen J, Cao J, Wang J, Jia R, Xue W, Li Y, Luo Y and Xie L 2013 Effects of fluoride on growth, body composition, and serum biochemical profile in a freshwater teleost, Cyprinus carpio. Environ. Toxicol. Chem. 32(10): 2315-2321.

Demelash H, Beyene A, Abebe Z and Melese A 2019 Fluoride concentration in ground water and prevalence of dental fluorosis in Ethiopian rift alley: systematic review and meta-analysis. BMC Public Health 19(1): 1-9.

El-Said GF and El-Sadaawy MM 2013 Seasonal variation of boron and fluoride in Tilapia nilotica from an Egyptian fish farm in relation to human health hazard assessment. Human Ecol. Risk Assess. Int. J. 19(4): 930-943.

Ghiglieri G, Balia R, Oggiano G and Pittalis D 2010 Prospecting for safe (low fluoride) groundwater in the Eastern African Rift: the Arumeru District (northern Tanzania). Hydrol. Earth Syst. Sci. 14(6): 1081-1091.

Gikunju JK, Maitho TE, Birkeland JM and Lökken P 1992 Fluoride in fish from lakes of great Rift Valley, Kenya. Ecol. Food Nutr. 27(2): 85-90.

Harikumar PS, Aravind A and Vasudevan S 2017 Assessment of water quality status of Guruvayur municipality. J. Environ. Protect. 08(02): 159-170.

Jagtap S, Yenkie MK, Labhsetwar $\mathrm{N}$ and Rayalu S 2012 Fluoride in drinking water and defluoridation of water. Chem. Rev. 112(4): 2454-2466.

Kaur R, Saxena A and Batra M 2017 A review study on fluoride toxicity in water and fishes: current status, toxicology and remedial measures. Int. J. Environ. Agric. Biotechnol. 2(1): 456-466.

Kimambo V, Bhattacharya P, Mtalo F, Mtamba J and Ahmad A 2019 Fluoride occurrence in groundwater systems at global scale and 
Bejumula et al. - Assessment of fluoride bioaccumulation potential in African catfish ...

status of defluoridation-State of the art. Groundw. Sustain. Dev. 9: 100223.

Kut KMK, Sarswat A, Srivastava A, Pittman CUand Mohan D 2016 A review of fluoride in African groundwater and local remediation methods. Groundw. Sustain. Dev. 2-3: 190-212.

Lima RL, Braun N, Kochhann D, Lazzari R, Neto JR, Moraes BS, Loro VL and Baldisserotto B 2011 Survival, growth and metabolic parameters of silver catfish, Rhamdia quelen, juveniles exposed to different waterborne nitrite levels. Neotrop. Ichthyol. 9(1): 147-152.

Malago J, Makoba E and Muzuka ANN 2017 Fluoride levels in surface and groundwater in Africa: a review. Am. J. Water Sci. Eng. 3(1): 1-17.

Mbabaye GK, Minja RJA, Mtalo F, Legonda I and Mkongo G 2018 Fluoride occurrence in domestic water supply sources in Tanzania: a case of Meru district Arusha region. Tanz. J. Sci. 44(3): 72-92.

Masawe K, Mtei KM and Machunda R 2019 Distribution of fluoride in beans and maize grown along the slope of Mount Meru, Tanzania. J. Biodiv. Environ. Sci. 15(5): 28-35.

Musiba MJ, Ngupula GW, Kashindye BB, Elison M, Shoko AP, Ndikumana J, Zziwa E and Katunzi 2014 Performance of locally formulated feeds for rearing of African catfish in Tanzania. Afr. Crop Sci. J. 22: 979-986.

Nawang SUSM, Ching FF and Senoo S 2019 Comparison on growth performance, body coloration changes and stress response of juvenile river catfish, Pangasius hypophthalmus reared in different tank background colour. Aquac. Res. 50(9): 2591-2599.

NBS (National Bureau of Statistics) 2019 Tanzania National Bureau of Statistics. Retrived on February, 2021 from: https://www.nbs.go.tz/index.php/en/

Olaniyi CO, Akimoju O, Sokunbi AE and Olayiwola OO 2020 Nutrition and reproductive performance of African catfish fed bitter kola (Garcinia kolal). Int. J. Aquac. Fish. Sci. 6(1): 001-007.

Parsons TR and Strickland JDH 1972 A practical handbook of seawater analysis. $2^{\text {nd }}$ ed,The Alger Press Ltd, Ottawa Canada.

Rizzu M, Tanda A, Canu L, Masawe K, Mtei K, Deroma MA, Roggero PP and Seddaiu G 2020 Fluoride uptake and translocation in food crops grown in fluoride-rich soils. $J$. Sci. Food Agric. 100(15): 5498-5509.

Roques JAC, Schram E, Spanings T,vanSchaik TV Abbink W, Boerrigter J, de Vries P, van de Vis H and Flik G 2015 The impact of elevated water nitrite concentration on physiology, growth and feed intake of African catfish Clarias gariepinus (Burchell 1822). Aquaculture Res. 46(6): 1384-1395.

Roy S and Dass G 2013 Fluoride contamination in drinking water: a review. Resour. Environ. 3(3): 53-58.

Schram E, Roques JAC, Abbink W, Spanings $\mathrm{T}$, De Vries $\mathrm{P}$, Bierman $\mathrm{S}$, van deVis $\mathrm{H}$ and Flik G 2010 The impact of elevated water ammonia concentration on physiology, growth and feed intake of African catfish (Clarias gariepinus). Aquac. 306: 108-115.

Shi X, Zhuang P, Zhang L, Feng G, Chen L, Liu J, Qu L and Wang R 2009 The bioaccumulation of fluoride ion $\left(\mathrm{F}^{-}\right)$in Siberian sturgeon (Acipenser baerii) under laboratory conditions. Chemosphere 75(3): 376-380.

Singh N and Tripathi M 2015 Fluoride toxicity in freshwater fishes and aquaculture: a review. Indian J. Life Sci. 4(2): 115-124.

Thole B, Masamba WRL and Mtalo FW2013 Water defluoridation by bauxite-gypsum magnesite (B-G-Mc) based filters calcined at 350 500C. Int. J. Phys. Sci. 8: 956-962.

Umaru J, Auta J, Oniye SJ and Bolorunduro PI2016Growth and economic performance of African catfish, Clarias gariepinus (Burchell, 1822) juveniles to imported and local feeds in floating bamboo cages. Int. J. Fish. Aquat. Studies 4(2): 221-226. 